\title{
Impact of Different Levels of Fertilizers on Growth Components of Two Vigna Species
}

\author{
Supriya Dixit ${ }^{*}$, R. K. Gupta \\ Department of Botany, D. V. College, Orai (Jalaun), 285001, Bundelkhand University, Jhansi, Uttar Pradesh, India
}

Received November 9, 2020; Revised January 29, 2021; Accepted February 17, 2021

\section{Cite This Paper in the following Citation Styles}

(a): [1] Supriya Dixit, R. K. Gupta , "Impact of Different Levels of Fertilizers on Growth Components of Two Vigna Species," Advances in Zoology and Botany, Vol. 9, No. 4, pp. 83 - 90, 2021. DOI: 10.13189/azb.2021.090402.

(b): Supriya Dixit, R. K. Gupta (2021). Impact of Different Levels of Fertilizers on Growth Components of Two Vigna Species. Advances in Zoology and Botany, 9(4), 83 - 90. DOI: 10.13189/azb.2021.090402.

Copyright $\bigcirc 2021$ by authors, all rights reserved. Authors agree that this article remains permanently open access under the terms of the Creative Commons Attribution License 4.0 International License

\begin{abstract}
Fertilizers are widely used by farmers in agricultural practices in form of chemical fertilizer, organic fertilizer and biofertilizer, supplying plants with nutrients for their optimal growth and production. In the beginning, farmers were delighted to get improved yield in agriculture, but gradually, chemical fertilizers began to show their ill impacts such as polluting water basins and leaching out, killing microorganisms and helpful insects, and also decreasing soil fertility. Biofertilizers, on the other hand, refer to articles containing live or latent microbes which help boost fertility of soil by either solubilizing phosphorus, fixing atmospheric nitrogen, decomposing organic waste or stimulating growth of plant through the synthesis of growth-promoting substances. A study was carried out to examine the impact of fertilizers (PSB and DAP) application on growth components of Vigna radiata and $V$. mungo. As a result, overall maximum value of experimental parameters such as seed germination percentage, root length, shoot length, fresh and dry weight of stem, chlorophyll content, phosphorus content, potassium content, nitrogen content as well as crude protein content were found with combined application of both fertilizers as compared to the control in both Vigna crops. Therefore, it was concluded that the application of biofertilizer with chemical fertilizer showed higher value for experimental parameters as compared to the control and also their single fertilizer treatments in both Vigna crops. The main purpose of the study was to look for the best fertilizer level either single or in combination of chemical fertilizer and biofertilizer, which could be applied to the experimental crops to obtain their enhanced growth components in addition to keeping sustainable and safe environment due to the reduction or minimize the use of
\end{abstract}

chemical fertilizers.

Keywords DAP, PSB, Growth Components, Vigna radiata and $V$. mungo

\section{Introduction}

Plants whether cultivated on the field or in a jar, utilize the inorganic minerals for their nourishment. Mineral elements as nitrogen $(\mathrm{N})$, phosphorus $(\mathrm{P})$ and potassium $(\mathrm{K})$ are needed in large amount, which are most likely to be in short supply in agricultural soils. Besides this, both nitrogen and phosphorus are essential nutrients of nearly all the biochemical substances that make existence possible for plants. Farmers inoculate the agricultural lands with different kinds of fertilizers to secure a preferable crop yield. Fertilizers serve as catalyst for optimal growth and production of plants. The usage of chemical fertilizers with large varieties of seeds and irrigation improves the agricultural productivity and helps to achieve food grain self-sufficiency [28]. Many experiments have shown that the usage of phosphorus fertilizers typically has a significant effect on crop yield as its reduction restricts plant reaction to certain nutrients [2]. But gradually chemical fertilizers begin to show their ill impacts such as polluting water basins and leaching out, killing microorganisms and helpful insects, rendering the crop more perceptive to disease invasions and decreasing soil fertility. Apart from this, application of biofertilizers to the soil improves the biomass that makes up all sorts of beneficial bacteria and fungi. So many microorganisms 
thrive in the soil, particularly in rhizosphere. A large amount of such microorganisms has a working interaction and shapes a systemic plant network. They have positive implications for plant development [36].

Biofertilizers are gaining quickness due to the increasing insistence on maintenance of soil health, reducing the environmental pollution and cut down on the use of chemicals in agriculture that will lead to sustainable agricultural production [30]. These are important components of sustainable farming which play a crucial role in maintaining long-lasting soil fertility and crop production sustainability [22]. Thus, reduce the dependency on chemical fertilizers to crop growth and yield improvement, and replace it with biofertilizers as they are comparatively low-cost inputs and eco-friendly to the sustainable agricultural system to save as well as protect the environment. In the present study, two experimental Vigna species were green gram (Vigna radiata L. Wilczek; var. sweta) also named as mung bean, and black gram (V. mungo L. Hepper; var. Azad-3) also known as urdbean. Both are annual herbaceous self-fertilized crops. Plants are rising to a height of 30 to $100 \mathrm{~cm}$ containing trifoliate leaves, along with yellow-colored flowers formed in axillary racemes. These are a good source of quickly digestible protein to the vegetarian population of the nation.

There are many studies that showed the combined application of chemical fertilizers and biofertilizers significantly influenced the growth and development of many crops and improved the crop yield thus, reduced the dependency on chemical fertilizers to increase their yield. Echinockloa frumentacea showed increased values of morphological and yield parameters with a combination of biofertilizer and synthetic fertilizer application than using either method alone [9]. Biofertilizers with a reduced amount of chemical fertilizers were recommended for better yield of chickpea [21]. Significantly higher values of saloid-P and Ca-P observed in soil with DAP and PSB seed treatment in groundnut [3]. Thus, the present study was undertaken to identify specific level of fertilizers with a reduced or minimized dose of chemical fertilizer to obtain maximum growth components of Vigna radiata and $V$. mungo crops.

\section{Materials and Methods}

To study the impact of different levels (single and their combinations) of chemical fertilizer (DAP) and biofertilizer (PSB) on growth components of Vigna radiata and $V$. mungo crops, a poly pot experiment, based on randomized complete block design (RCBD) with three replicates of 10 plants per treatment was carried out during kharif season (2017) at department of Botany, D. V. College, Orai (Jalaun) in Bundelkhand region of Uttar Pradesh, India. Bundelkhand region lies in south-west corner of Uttar Pradesh (India), and is predominantly a drought prone area which is extended $24^{\circ} 11^{\prime}$ and $26^{\circ} 27^{\prime} \mathrm{N}$ latitude and $78^{\circ} 17^{\prime}$ and $81^{\circ} 34^{\prime} \mathrm{E}$ longitudes with an average altitude ranging 250 to $300 \mathrm{~m}$ above MSL (mean sea level) [19].

\section{Collection of materials:}

For the present study purpose, black soil, locally called as 'kabar' was collected from neighboring localities of Orai. Experimental crops seed (certified) and PSB (Phosphate Solubilizing Bacteria) biofertilizer culture were obtained from kendriya krashi beej bhandar, Orai whereas, chemical fertilizer as DAP (Diammonium Phosphate) obtained from IFFCO, Orai.

\section{Soil treatments:}

There were total sixteen soil treatments $\left(T_{1}\right.$ to $\left.T_{15}\right)$ prepared containing different doses of DAP (as $0.25 \mathrm{~g}$, $0.50 \mathrm{~g}$ and $1.00 \mathrm{~g}$ of DAP per $\mathrm{kg}$ of soil) and PSB (as 2.50 $\mathrm{g}, 5.00 \mathrm{~g}$ and $10.00 \mathrm{~g}$ of PSB per kg of soil) with a control treatment $\left(\mathrm{T}_{0}\right)$ i.e. without fertilizer application (Table-1). Fixed doses of experimental fertilizers were mixed well with calculated amount of soil to prepare different fertilizer levels.

Table 1. Different levels of chemical fertilizer (DAP) and biofertilizer (PSB)

\begin{tabular}{ccc}
\hline S. No. & Treatments & Doses (in per kg of soil) \\
\hline 1 & $\mathrm{~T}_{0}$ & Control (Without fertilizer) \\
2 & $\mathrm{~T}_{1}$ & $0.25 \mathrm{~g}$ of DAP \\
3 & $\mathrm{~T}_{2}$ & $0.50 \mathrm{~g}$ of DAP \\
4 & $\mathrm{~T}_{3}$ & $1.00 \mathrm{~g}$ of DAP \\
5 & $\mathrm{~T}_{4}$ & $2.50 \mathrm{~g}$ of PSB \\
6 & $\mathrm{~T}_{5}$ & $10.00 \mathrm{~g}$ of PSB \\
7 & $\mathrm{~T}_{6}$ & $0.25 \mathrm{~g}$ of $\mathrm{DAP} \times 2.50 \mathrm{~g}$ of PSB \\
8 & $\mathrm{~T}_{7}$ & $0.25 \mathrm{~g}$ of DAP $\times 5.00 \mathrm{~g}$ of PSB \\
9 & $\mathrm{~T}_{8}$ & $0.25 \mathrm{~g}$ of $\mathrm{DAP} \times 10.00 \mathrm{~g}$ of PSB \\
10 & $\mathrm{~T}_{9}$ & $0.50 \mathrm{~g}$ of $\mathrm{DAP} \times 2.50 \mathrm{~g}$ of PSB \\
11 & $\mathrm{~T}_{10}$ & $0.50 \mathrm{~g}$ of $\mathrm{DAP} \times 5.00 \mathrm{~g}$ of PSB \\
12 & $\mathrm{~T}_{11}$ & $0.50 \mathrm{~g}$ of $\mathrm{DAP} \times 10.00 \mathrm{~g}$ of PSB \\
13 & $\mathrm{~T}_{12}$ & $1.00 \mathrm{~g}$ of $\mathrm{DAP} \times 2.50 \mathrm{~g}$ of PSB \\
14 & $\mathrm{~T}_{13}$ & $1.00 \mathrm{~g}$ of $\mathrm{DAP} \times 5.00 \mathrm{~g}$ of PSB \\
15 & $\mathrm{~T}_{14}$ & $1.00 \mathrm{~g}$ of $\mathrm{DAP} \times 10.00 \mathrm{~g}$ of PSB \\
16 & $\mathrm{~T}_{15}$ &
\end{tabular}

\section{Sowing of seeds:}

Plants were raised in black coloured 12 inches poly flower pots with a bottom and few on the upper edge drainage holes. Before sowing, Vigna seed surface was sterilized with $0.1 \% \mathrm{HgCl}_{2}$ for two minutes and thoroughly washed with distilled water. Then, the seeds were sown in poly pots with treated soil according to the 
Table-1. As many as 10 seeds were sown in each pot.

\section{Observations and data analysis:}

Experimental parameters of both species of Vigna crop were observed, analyzed and recorded at requisite time intervals from seed germination to harvesting. Seed germination percentage was recorded at 7 DAS (Days after sowing). Length of root and shoot was measured by using a centimeter scale and the mean value was recorded by randomly selected three normal seedlings. To measure fresh weight of stem, plant samples were cut with sharp blade and properly water washed. After that blotted with blotting paper and weighed in gram (g), whereas dry weight of the same samples was determined by drying the finally chopped and mixed sample in a forced drought oven at $70^{\circ} \mathrm{C}$ for 24 hours to constant weight. The samples were taken out from the oven and placed in a desiccator cooled for about an hour and weighed in gram. Chlorophyll content of fresh leaves of plant sample was determined by Petering method [27]. Phosphorus content of leaves was determined by the molybdenum reduced phosphomolybdic acid blue colour method in $\mathrm{H}_{2} \mathrm{SO}_{4}$ system. The blue colour was determined in Elico-CL-20A photo-electric colorimeter using red filter. Potassium content was measured turbidimetrically. The turbidity produced at $20^{\circ} \mathrm{C}$ under standardized conditions was estimated in Elico-CL-20A photo-electric colorimeter using red filter. Nitrogen content of leaves was determined by semi-micro-kjeldahl method and the crude protein content of leaves was calculated by the correction factor $(\mathrm{N} \times 6.25)$ [10]. All these growth components were recorded at requisite time intervals (30 and 60 DAS) of crop growing period. Average values of the experimental parameters were shown in Table-2A, $2 \mathrm{~B}, 3 \mathrm{~A}$ and $3 \mathrm{~B}$. The data for the various experimental parameters in the present study were ANOVA tested and the significance of differences between control and each treatment was determined by using the value of least significant difference (L.S.D.) at $\mathrm{P}=0.05$ and $\mathrm{P}=0.01$ and presented within tables.

Table 2A. Effect of different levels of chemical fertilizer (DAP) and biofertilizer (PSB) on Vigna radiata

\begin{tabular}{|c|c|c|c|c|c|c|c|c|c|c|}
\hline \multirow[t]{2}{*}{ Fertilizer } & \multirow[t]{2}{*}{$\begin{array}{l}\text { Treatment Level } \\
\text { (g per kg soil) }\end{array}$} & \multirow{2}{*}{$\begin{array}{c}\text { Seed } \\
\text { germination (\%) } \\
7^{\text {th }} \text { DAS }\end{array}$} & \multicolumn{2}{|c|}{ Root length (cm) } & \multicolumn{2}{|c|}{$\begin{array}{l}\text { Shoot length } \\
\text { (cm) }\end{array}$} & \multicolumn{2}{|c|}{$\begin{array}{l}\text { Fresh weight } \\
\text { (g) of stem }\end{array}$} & \multicolumn{2}{|c|}{$\begin{array}{c}\text { Dry weight (g) } \\
\text { of stem }\end{array}$} \\
\hline & & & $\begin{array}{c}30 \\
\text { DAS }\end{array}$ & 60 DAS & $\begin{array}{c}30 \\
\text { DAS }\end{array}$ & $\begin{array}{c}60 \\
\text { DAS }\end{array}$ & $\begin{array}{c}30 \\
\text { DAS }\end{array}$ & $\begin{array}{c}60 \\
\text { DAS }\end{array}$ & $\begin{array}{c}30 \\
\text { DAS }\end{array}$ & $\begin{array}{c}60 \\
\text { DAS }\end{array}$ \\
\hline \multirow[t]{2}{*}{ Control } & $\mathrm{T}_{0}$ & 83.33 & 4.46 & 9.23 & 8.50 & 24.06 & 1.42 & 2.37 & 0.38 & 0.45 \\
\hline & $\mathrm{T}_{1}$ & 86.66 & 4.80 & 12.13 & 9.06 & 30.33 & 1.93 & 2.72 & 0.45 & 0.54 \\
\hline \multirow[t]{3}{*}{ DAP } & $\mathrm{T}_{2}$ & 83.33 & 4.73 & 10.13 & 8.83 & 28.90 & 1.81 & 2.57 & 0.42 & 0.55 \\
\hline & $\mathrm{T}_{3}$ & 83.33 & 4.60 & 9.30 & 8.73 & 27.73 & 1.54 & 2.41 & 0.51 & 0.65 \\
\hline & $\mathrm{T}_{4}$ & 83.33 & 4.66 & 9.86 & 9.00 & 27.13 & 1.81 & 2.76 & 0.44 & 0.59 \\
\hline \multirow[t]{6}{*}{ PSB } & $\mathrm{T}_{5}$ & 86.66 & 4.83 & 10.50 & 9.90 & 28.70 & 1.92 & 2.94 & 0.49 & 0.65 \\
\hline & $\mathrm{T}_{6}$ & 93.33 & 5.06 & 11.93 & 10.20 & 29.90 & 2.12 & 3.10 & 0.53 & 0.69 \\
\hline & $\mathrm{T}_{7}$ & 90.00 & 4.93 & 12.20 & 9.40 & 31.43 & 2.19 & 2.92 & 0.47 & 0.63 \\
\hline & $\mathrm{T}_{8}$ & 93.33 & 5.10 & 12.53 & 9.96 & 32.13 & 2.39 & 3.12 & 0.55 & 0.71 \\
\hline & $\mathrm{T}_{9}$ & 96.66 & 5.23 & 12.96 & 10.93 & 32.93 & 2.71 & 3.23 & 0.55 & 0.74 \\
\hline & $\mathrm{T}_{10}$ & 93.33 & 5.40 & 12.33 & 10.10 & 31.90 & 2.33 & 3.15 & 0.57 & 0.70 \\
\hline \multirow[t]{7}{*}{$\mathrm{DAP} \times \mathrm{PSB}$} & $\mathrm{T}_{11}$ & 96.66 & 5.56 & 13.03 & 10.43 & 32.93 & 2.46 & 3.37 & 0.59 & 0.79 \\
\hline & $\mathrm{T}_{12}$ & 100 & 5.83 & 14.83 & 11.00 & 33.56 & 2.79 & 3.78 & 0.59 & 0.83 \\
\hline & $\mathrm{T}_{13}$ & 93.33 & 5.63 & 12.60 & 12.10 & 33.70 & 2.62 & 3.45 & 0.53 & 0.67 \\
\hline & $\mathrm{T}_{14}$ & 96.66 & 6.13 & 13.36 & 13.50 & 34.20 & 2.73 & 3.77 & 0.57 & 0.76 \\
\hline & $\mathrm{T}_{15}$ & 100 & 6.30 & 15.20 & 15.00 & 34.70 & 2.98 & 3.89 & 0.57 & 0.77 \\
\hline & $\mathrm{P}=0.05 \mathrm{DAP}$ & 5.77 & 0.36 & 0.48 & 0.41 & 0.57 & 0.25 & 0.23 & 0.03 & 0.05 \\
\hline & $\mathrm{P}=0.01 \mathrm{DAP}$ & 7.18 & 0.45 & 0.59 & 0.51 & 0.71 & 0.32 & 0.28 & 0.03 & 0.06 \\
\hline \multirow{4}{*}{ L.S.D. } & $\mathrm{P}=0.05 \mathrm{PSB}$ & 5.77 & 0.36 & 0.48 & 0.41 & 0.57 & 0.25 & 0.23 & 0.03 & 0.05 \\
\hline & $\mathrm{P}=0.01 \mathrm{PSB}$ & 7.18 & 0.45 & 0.59 & 0.51 & 0.71 & 0.32 & 0.28 & 0.03 & 0.06 \\
\hline & $\mathrm{P}=0.05 \mathrm{DAP} \times \mathrm{PSB}$ & 15.80 & 0.99 & 1.31 & 1.13 & 1.57 & 0.70 & 0.62 & 0.08 & 0.13 \\
\hline & $\mathrm{P}=0.01 \mathrm{DAP} \times \mathrm{PSB}$ & 18.52 & 1.16 & 1.53 & 1.32 & 1.84 & 0.82 & 0.72 & 0.09 & 0.15 \\
\hline
\end{tabular}


Table 2B. Effect of different levels of chemical fertilizer (DAP) and biofertilizer (PSB) on Vigna radiata

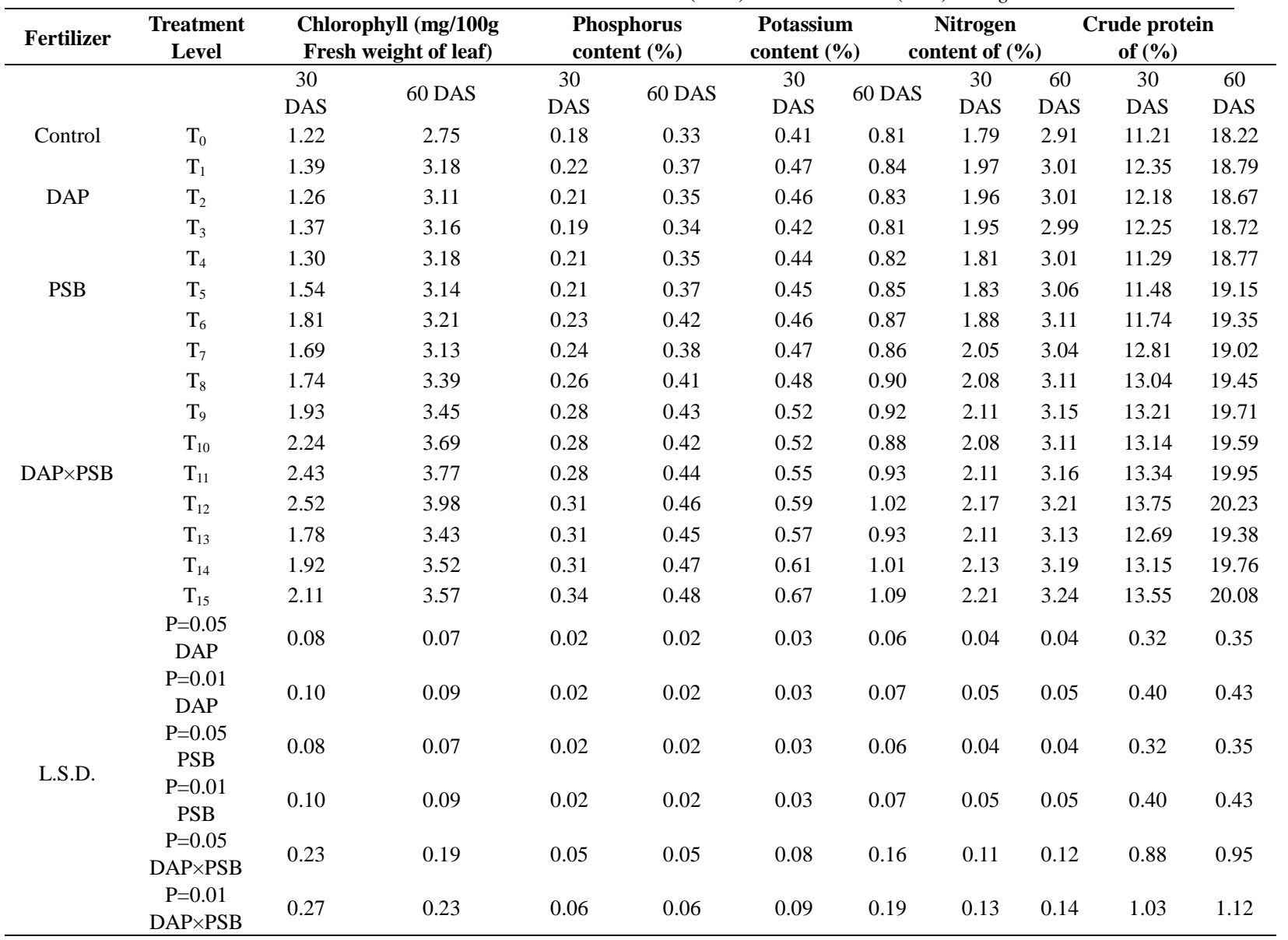

Table 3A. Effect of different levels of chemical fertilizer (DAP) and biofertilizer (PSB) on Vigna mungo

\begin{tabular}{|c|c|c|c|c|c|c|c|c|c|c|}
\hline \multirow[t]{3}{*}{ Fertilizer } & \multirow[t]{3}{*}{$\begin{array}{c}\text { Treatment Level } \\
\text { (g per kg soil) }\end{array}$} & \multirow{3}{*}{$\begin{array}{c}\text { Seed } \\
\text { germination (\%) } \\
7^{\text {th }} \text { DAS }\end{array}$} & \multicolumn{2}{|c|}{$\begin{array}{l}\text { Root length } \\
(\mathrm{cm})\end{array}$} & \multicolumn{2}{|c|}{$\begin{array}{c}\text { Shoot length } \\
(\mathrm{cm})\end{array}$} & \multicolumn{2}{|c|}{$\begin{array}{c}\text { Fresh weight } \\
\text { (g) of stem }\end{array}$} & \multicolumn{2}{|c|}{$\begin{array}{c}\text { Dry weight (g) } \\
\text { of stem }\end{array}$} \\
\hline & & & 30 & 60 & 30 & 60 & 30 & 60 & 30 & 60 \\
\hline & & & DAS & DAS & DAS & DAS & DAS & DAS & DAS & DAS \\
\hline \multirow[t]{2}{*}{ Control } & $\mathrm{T}_{0}$ & 83.33 & 4.13 & 8.80 & 8.23 & 22.20 & 1.45 & 2.41 & 0.32 & 0.51 \\
\hline & $\mathrm{T}_{1}$ & 90.00 & 4.63 & 9.63 & 8.60 & 24.00 & 1.62 & 2.53 & 0.41 & 0.64 \\
\hline \multirow{3}{*}{ DAP } & $\mathrm{T}_{2}$ & 86.66 & 4.33 & 9.56 & 8.43 & 22.86 & 1.47 & 2.43 & 0.36 & 0.57 \\
\hline & $\mathrm{T}_{3}$ & 83.33 & 4.23 & 9.10 & 8.46 & 23.83 & 1.53 & 2.46 & 0.41 & 0.61 \\
\hline & $\mathrm{T}_{4}$ & 86.66 & 4.56 & 9.53 & 8.93 & 25.16 & 1.61 & 2.50 & 0.45 & 0.62 \\
\hline \multirow{2}{*}{ PSB } & $\mathrm{T}_{5}$ & 90.00 & 4.86 & 9.76 & 9.43 & 26.80 & 1.70 & 2.56 & 0.53 & 0.73 \\
\hline & $\mathrm{T}_{6}$ & 96.66 & 5.33 & 10.00 & 9.76 & 28.73 & 1.82 & 2.67 & 0.56 & 0.79 \\
\hline \multirow{9}{*}{$\mathrm{DAP} \times \mathrm{PSB}$} & $\mathrm{T}_{7}$ & 93.33 & 5.00 & 9.96 & 9.10 & 25.96 & 1.72 & 2.60 & 0.46 & 0.69 \\
\hline & $\mathrm{T}_{8}$ & 96.66 & 5.30 & 10.23 & 9.83 & 27.40 & 1.78 & 2.66 & 0.55 & 0.77 \\
\hline & $\mathrm{T}_{9}$ & 100 & 5.66 & 10.46 & 10.20 & 29.40 & 1.95 & 2.77 & 0.63 & 0.83 \\
\hline & $\mathrm{T}_{10}$ & 96.66 & 5.53 & 10.56 & 10.06 & 28.13 & 1.93 & 2.76 & 0.64 & 0.75 \\
\hline & $\mathrm{T}_{11}$ & 100 & 5.83 & 10.70 & 10.63 & 29.26 & 2.04 & 2.81 & 0.66 & 0.83 \\
\hline & $\mathrm{T}_{12}$ & 100 & 6.23 & 10.86 & 11.06 & 30.40 & 2.19 & 2.93 & 0.71 & 0.86 \\
\hline & $\mathrm{T}_{13}$ & 100 & 5.93 & 11.00 & 9.46 & 27.00 & 1.82 & 2.67 & 0.55 & 0.73 \\
\hline & $\mathrm{T}_{14}$ & 100 & 6.20 & 11.43 & 10.23 & 28.46 & 1.93 & 2.74 & 0.65 & 0.81 \\
\hline & $\mathrm{T}_{15}$ & 100 & 6.50 & 11.63 & 10.53 & 29.66 & 2.09 & 2.85 & 0.69 & 0.85 \\
\hline \multirow{6}{*}{ L.S.D. } & $\mathrm{P}=0.05 \mathrm{DAP}$ & 5.99 & 0.29 & 0.25 & 0.39 & 0.56 & 0.18 & 0.06 & 0.03 & 0.03 \\
\hline & $\mathrm{P}=0.01 \mathrm{DAP}$ & 7.45 & 0.37 & 0.31 & 0.49 & 0.70 & 0.22 & 0.07 & 0.03 & 0.03 \\
\hline & $\mathrm{P}=0.05 \mathrm{PSB}$ & 5.99 & 0.29 & 0.25 & 0.39 & 0.56 & 0.18 & 0.06 & 0.03 & 0.03 \\
\hline & $\mathrm{P}=0.01 \mathrm{PSB}$ & 7.45 & 0.37 & 0.31 & 0.49 & 0.70 & 0.22 & 0.07 & 0.03 & 0.03 \\
\hline & $\mathrm{P}=0.05 \mathrm{DAP} \times \mathrm{PSB}$ & 16.40 & 0.81 & 0.67 & 1.07 & 1.54 & 0.49 & 0.15 & 0.08 & 0.08 \\
\hline & $\mathrm{P}=0.01 \mathrm{DAP} \times \mathrm{PSB}$ & 19.22 & 0.95 & 0.79 & 1.25 & 1.81 & 0.58 & 0.18 & 0.09 & 0.09 \\
\hline
\end{tabular}


Table 3B. Effect of different levels of chemical fertilizer (DAP) and biofertilizer (PSB) on Vigna mungo

\begin{tabular}{|c|c|c|c|c|c|c|c|c|c|c|c|}
\hline \multirow[t]{3}{*}{ Fertilizer } & \multirow[t]{3}{*}{$\begin{array}{l}\text { Treatment } \\
\text { Level }\end{array}$} & \multicolumn{2}{|c|}{$\begin{array}{c}\text { Chlorophyll } \\
\text { (mg/100g Fresh } \\
\text { weight of leaf) }\end{array}$} & \multicolumn{2}{|c|}{$\begin{array}{l}\text { Phosphorus } \\
\text { content (\%) }\end{array}$} & \multicolumn{2}{|c|}{$\begin{array}{l}\text { Potassium } \\
\text { content (\%) }\end{array}$} & \multicolumn{2}{|c|}{$\begin{array}{c}\text { Nitrogen content } \\
(\%)\end{array}$} & \multicolumn{2}{|c|}{$\begin{array}{l}\text { Crude protein } \\
\text { content (\%) }\end{array}$} \\
\hline & & 30 & 60 & 30 & 60 & 30 & 60 & & 60 & 30 & 60 \\
\hline & & DAS & DAS & DAS & DAS & DAS & DAS & 30 DAS & DAS & DAS & DAS \\
\hline \multirow[t]{2}{*}{ Control } & $\mathrm{T}_{0}$ & 1.25 & 2.63 & 0.19 & 0.33 & 0.41 & 0.75 & 1.78 & 2.27 & 11.07 & 14.21 \\
\hline & $\mathrm{T}_{1}$ & 1.37 & 3.08 & 0.27 & 0.39 & 0.49 & 0.83 & 1.84 & 2.51 & 11.49 & 16.01 \\
\hline \multirow[t]{3}{*}{ DAP } & $\mathrm{T}_{2}$ & 1.31 & 2.81 & 0.23 & 0.35 & 0.42 & 0.78 & 1.81 & 2.45 & 11.34 & 15.33 \\
\hline & $\mathrm{T}_{3}$ & 1.35 & 2.92 & 0.24 & 0.38 & 0.44 & 0.81 & 1.82 & 2.48 & 11.41 & 15.43 \\
\hline & $\mathrm{T}_{4}$ & 1.28 & 2.71 & 0.22 & 0.35 & 0.44 & 0.81 & 1.80 & 2.55 & 11.30 & 15.93 \\
\hline \multirow[t]{6}{*}{ PSB } & $\mathrm{T}_{5}$ & 1.35 & 2.80 & 0.23 & 0.36 & 0.44 & 0.82 & 1.84 & 2.56 & 11.49 & 15.96 \\
\hline & $\mathrm{T}_{6}$ & 1.43 & 3.07 & 0.24 & 0.38 & 0.49 & 0.84 & 1.86 & 2.59 & 11.63 & 16.18 \\
\hline & $\mathrm{T}_{7}$ & 1.41 & 3.13 & 0.28 & 0.41 & 0.51 & 0.86 & 1.86 & 2.61 & 11.61 & 16.25 \\
\hline & $\mathrm{T}_{8}$ & 1.49 & 3.21 & 0.32 & 0.44 & 0.53 & 0.89 & 1.87 & 2.63 & 11.72 & 16.43 \\
\hline & $\mathrm{T}_{9}$ & 1.53 & 3.35 & 0.32 & 0.45 & 0.54 & 0.91 & 1.89 & 2.64 & 11.81 & 16.53 \\
\hline & $\mathrm{T}_{10}$ & 1.65 & 3.45 & 0.31 & 0.48 & 0.58 & 0.94 & 1.91 & 2.69 & 11.91 & 16.49 \\
\hline \multirow[t]{8}{*}{$\mathrm{DAP} \times \mathrm{PSB}$} & $\mathrm{T}_{11}$ & 1.73 & 3.52 & 0.37 & 0.51 & 0.61 & 0.96 & 1.96 & 2.75 & 12.24 & 17.18 \\
\hline & $\mathrm{T}_{12}$ & 1.82 & 3.66 & 0.39 & 0.54 & 0.67 & 1.07 & 1.97 & 2.77 & 12.33 & 17.33 \\
\hline & $\mathrm{T}_{13}$ & 1.52 & 3.32 & 0.29 & 0.45 & 0.54 & 0.91 & 1.87 & 2.67 & 11.74 & 16.69 \\
\hline & $\mathrm{T}_{14}$ & 1.61 & 3.44 & 0.34 & 0.48 & 0.58 & 0.93 & 1.91 & 2.68 & 11.92 & 16.74 \\
\hline & $\mathrm{T}_{15}$ & 1.68 & 3.55 & 0.33 & 0.50 & 0.61 & 0.94 & 1.95 & 2.71 & 12.19 & 16.97 \\
\hline & $\mathrm{P}=0.05 \mathrm{DAP}$ & 0.05 & 0.11 & 0.03 & 0.02 & 0.03 & 0.05 & 0.03 & 0.03 & 0.13 & 0.43 \\
\hline & $\mathrm{P}=0.01 \mathrm{DAP}$ & 0.06 & 0.13 & 0.03 & 0.02 & 0.03 & 0.06 & 0.03 & 0.03 & 0.16 & 0.54 \\
\hline & $\mathrm{P}=0.05 \mathrm{PSB}$ & 0.05 & 0.11 & 0.03 & 0.02 & 0.03 & 0.05 & 0.03 & 0.03 & 0.13 & 0.43 \\
\hline \multirow[t]{3}{*}{ L.S.D. } & $\mathrm{P}=0.01 \mathrm{PSB}$ & 0.06 & 0.13 & 0.03 & 0.02 & 0.03 & 0.06 & 0.03 & 0.03 & 0.16 & 0.54 \\
\hline & $\begin{array}{c}\mathrm{P}=0.05 \\
\mathrm{DAP} \times \mathrm{PSB}\end{array}$ & 0.14 & 0.29 & 0.08 & 0.05 & 0.08 & 0.14 & 0.08 & 0.08 & 0.36 & 1.18 \\
\hline & $\begin{array}{c}\mathrm{P}=0.01 \\
\mathrm{DAP} \times \mathrm{PSB}\end{array}$ & 0.17 & 0.34 & 0.09 & 0.06 & 0.09 & 0.17 & 0.09 & 0.09 & 0.42 & 1.39 \\
\hline
\end{tabular}

\section{Results and Discussion}

The single fertilizer application of PSB with increasing tested levels showed significantly the most favourable impact on experimental growth components as compared to the control in both experimental Vigna crops whereas, DAP with minimum tested level showed the most favourable impact on most of the experimental parameters. While, overall maximum values of the all experimental parameters recorded with combined application of PSB and DAP in both Vigna crops.

In case of Vigna radiata, the combined fertilizer application of $0.50 \mathrm{~g}$ DAP $\times 10.00 \mathrm{~g}$ PSB $\left(\mathrm{T}_{12}\right)$ and $1.00 \mathrm{~g}$ $\mathrm{DAP} \times 10.00 \mathrm{~g}$ PSB per $\mathrm{kg}$ soil $\left(\mathrm{T}_{15}\right)$ showed the overall maximum seed germination (100 percent) at 7 DAS. Overall maximum value of root length $(6.30 \mathrm{~cm}$ and 15.20 $\mathrm{cm}$ at 30 and 60 DAS respectively), shoot length (15.00 $\mathrm{cm}$ and $34.70 \mathrm{~cm}$ at 30 and 60 DAS respectively), fresh weight of stem (2.98 g and $3.89 \mathrm{~g}$ at 30 and 60 DAS respectively), phosphorus content ( 0.34 and 0.48 percent at 30 and 60 DAS respectively), potassium content (0.67 and 1.09 percent at 30 and 60 DAS respectively), and nitrogen content (2.21 and 3.24 percent at 30 and 60 DAS respectively) of leaves found with the application of 1.00 g DAP $\times 10.00$ g PSB per kg soil $\left(T_{15}\right)$ as compared to the control $\left(\mathrm{T}_{0}\right)$, whereas overall maximum dry weight of stem at 30 DAS (0.59 g) recorded with application of 0.50 $\mathrm{g}$ of $\mathrm{DAP} \times 5.00 \mathrm{~g}$ of PSB $\left(\left(\mathrm{T}_{11}\right)\right.$ and $0.50 \mathrm{~g} \mathrm{DAP} \times 10.00 \mathrm{~g}$ PSB $\left(\mathrm{T}_{12}\right)$, and at 60 DAS $(0.83 \mathrm{~g})$ with $0.50 \mathrm{~g}$ $\mathrm{DAP} \times 10.00$ g PSB $\left(\mathrm{T}_{12}\right)$, while chlorophyll content $(2.52$ $\mathrm{mg}$ and $3.98 \mathrm{mg}$ at 30 and 60 DAS respectively) as well as crude protein content (13.75 and 20.23 percent at 30 and 60 DAS respectively) recorded also with $0.50 \mathrm{~g}$ $\mathrm{DAP} \times 10.00 \mathrm{~g}$ PSB $\left(\mathrm{T}_{12}\right)$ level (Table-2A and $\left.2 \mathrm{~B}\right)$. The similar effect of PSB was observed in green gram [37] and in other crops [17,31,34].

In case of $V$. mungo, the combined fertilizer application of $0.25 \mathrm{~g}$ DAP $\times 10.00 \mathrm{~g}$ PSB $\left(\mathrm{T}_{9}\right), 0.50 \mathrm{~g} \mathrm{DAP} \times 5.00 \mathrm{~g}$ PSB $\left(T_{11}\right), 0.50$ g $D A P \times 10.00$ g PSB $\left(T_{12}\right), 1.00 \mathrm{~g}$ $\mathrm{DAP} \times 2.50$ g PSB $\left(\mathrm{T}_{13}\right), 1.00$ g DAP $\times 5.00$ g PSB $\left(\mathrm{T}_{14}\right)$, and $1.00 \mathrm{~g}$ DAP $\times 10.00 \mathrm{~g}$ PSB per $\mathrm{kg}$ soil $\left(\mathrm{T}_{15}\right)$ levels showed overall maximum seed germination percentage (100) at 7 DAS, while application of $1.00 \mathrm{~g}$ DAP $\times 10.00 \mathrm{~g}$ PSB per kg soil $\left(\mathrm{T}_{15}\right)$ level showed overall maximum root 
length $(6.50 \mathrm{~cm}$ and $11.63 \mathrm{~cm}$ at 30 and 60 DAS respectively). The application of $0.50 \mathrm{~g} \mathrm{DAP} \times 10.00 \mathrm{~g}$ PSB per $\mathrm{kg}$ soil $\left(\mathrm{T}_{12}\right)$ level recorded overall maximum shoot length $(11.06 \mathrm{~cm}$ and $30.40 \mathrm{~cm}$ at 30 and 60 DAS respectively), fresh weight of stem (2.19 $\mathrm{g}$ and $2.93 \mathrm{~g}$ at 30 and 60 DAS respectively), dry weight of stem $(0.71 \mathrm{~g}$ and $0.86 \mathrm{~g}$ at 30 and 60 DAS respectively), chlorophyll content $(1.82 \mathrm{mg}$ and $3.66 \mathrm{mg}$ at 30 and 60 DAS respectively), phosphorus content ( 0.39 and 0.54 percent at 30 and 60 DAS respectively), potassium content (0.67 and 1.07 percent at 30 and 60 DAS respectively), nitrogen content (1.97 and 2.77 percent at 30 and 60 DAS respectively), and crude protein content (12.33 and 17.33 percent at 30 and 60 DAS respectively) of leaves as compared to the control (Table-3A and 3B). More or less similar findings were observed in black gram [29,33].

Biofertilizers with fixative bacteria increased the absorption potential of plant and dry material in plant [32]. Phosphorus solubilizing bacteria supported the phosphorus solubilization process in the soil to increase the phosphorus availability to plants [18]. Various growth parameters of cereals are found significantly changed with the Azospirillum inoculation $[7,8]$.

The treatments with PSB alone or in group of compatible strains with or without external application of chemical NPK gave more germination index in rice (Oryza sativa) and bean seeds (Vigna unguiculata) [13]. Bacteria enhanced the root growth in plants which in turn improved nutrient uptake and water absorption from soil and favoured the improvement in crop yield [23]; similar findings were observed with the rice crop [12]. Higher values for growth in both root and shoot length and biomass were recorded with the application of PSB alone or in group of compatible strains with or without chemical fertilizer in Oryza sativa and Vigna unguiculata than control [13].

Significantly increased chlorophyll content in corn (Zea mays L.) leaves was observed with the application of biofertilizer and urea [20]. The chlorophyll content was found increased due to the increased of nitrogen content in the plants attributed to the nutrients release in available forms in the soil through the microbial action $[4,5]$. Similar results were recorded in Chamaedorea elegans with the biofertilizer application [14]. Combined application of biofertilizer and chemical fertilizer showed increased fresh and dry weights of leaves in Spathiphyllum illusion [1].

Biofertilizer has gigantic potential for improving plant nutrition by substituting chemical fertilizers [12]. PSB and KSB enhanced microbial count in soil which is capable for solubilizing insoluble form of nutrient and enhanced nutrient uptake and saving of 25 percent fertilizer dose of phosphorus and potash [16]. Besides the biological nitrogen fixation, root colonizing bacteria produced the plant growth promoting substances which were responsible to the increased crop yield [26].
In the present study, PSB and DAP both positively influenced the growth components of both Vigna crops over the control. Previous study showed that the DAP fertilization had positive effects on stem thickness of Narcissus tazetta [35]. Reduction in the use of chemical fertilizers up to 50 percent was noticed through the biofertilizer application in of fennel plants without any reduction in growth of plants and yield [11,15,24]. Improved soil quality along with the growth and development in maize plants was recorded with the application of PSB [25]. PSB in addition to phosphate solubilization, is also capable of producing growth hormones such as auxins, cytokinins and gibberellins, vitamins, antibiotics, siderophores etc. and due to this property, they enhance plant growth and suppress the soil bearing pathogens and also improve physico-chemical properties of the soil and sustain soil fertility [6].

\section{Conclusions}

It concluded from the study that the interaction level $0.50 \mathrm{~g}$ DAP $\times 10.00 \mathrm{~g}$ PSB per $\mathrm{kg}$ soil $\left(\mathrm{T}_{12}\right)$ and $1.00 \mathrm{~g}$ $\mathrm{DAP} \times 10.00 \mathrm{~g}$ PSB per $\mathrm{kg}$ soil $\left(\mathrm{T}_{15}\right)$ were the most favourable to seed germination in Vigna radiata. The interaction level $1.00 \mathrm{~g}$ DAP $\times 10.00 \mathrm{~g}$ PSB per $\mathrm{kg}$ soil $\left(\mathrm{T}_{15}\right)$ significantly influenced the root and shoot length, fresh weight of stem as well as phosphorus, potassium and nitrogen content of leaves, whereas interaction level 0.50 g DAP $\times 10.00$ g PSB $\left(T_{12}\right)$ significantly influenced the chlorophyll and crude protein content of leaves, and dry weight of stem along with $0.50 \mathrm{~g}$ DAP $\times 5.00 \mathrm{~g}$ PSB $\left(\mathrm{T}_{11}\right)$ in $V$. radiata.

In case of $V$. mungo, interaction level $0.25 \mathrm{~g}$ $\mathrm{DAP} \times 10.00$ g PSB $\left(\mathrm{T}_{9}\right), 0.50$ g $\mathrm{DAP} \times 5.00$ g PSB $\left(\mathrm{T}_{11}\right)$, $0.50 \mathrm{~g}$ DAP $\times 10.00 \mathrm{~g}$ PSB $\left(\mathrm{T}_{12}\right), 1.00 \mathrm{~g} \mathrm{DAP} \times 2.50 \mathrm{~g}$ PSB $\left(\mathrm{T}_{13}\right), \quad 1.00 \mathrm{~g} \mathrm{DAP} \times 5.00 \mathrm{~g}$ PSB $\left(\mathrm{T}_{14}\right)$ and $1.00 \mathrm{~g}$ $\mathrm{DAP} \times 10.00 \mathrm{~g}$ PSB per $\mathrm{kg}$ soil $\left(\mathrm{T}_{15}\right)$ were the most favourable conditions to the seed germination. The interaction level $1.00 \mathrm{~g}$ DAP $\times 10.00 \mathrm{~g}$ PSB per $\mathrm{kg}$ soil $\left(\mathrm{T}_{15}\right)$ significantly influenced the root length, whereas interaction level 0.50 g $\mathrm{DAP} \times 10.00 \mathrm{~g}$ PSB $\left(\mathrm{T}_{12}\right)$ significantly influenced the shoot length, fresh and dry weight of stem as well as chlorophyll, phosphorus, potassium, nitrogen and crude protein content of leaves in V. mungo.

The soil treatment with combined application of chemical fertilizer (DAP) and biofertilizer (PSB) was found significant on growth components of both Vigna crops as compared to the control. Therefore, it suggested that the combination of chemical fertilizer and biofertilizer can reduce the dependency on chemical fertilizers alone to improve crop growth and yield for sustainable agricultural system.

The present investigation is the primary stage of study to analyze the impact of combined application of chemical 
fertilizer (DAP) and biofertilizer (PSB) on growth components of Vigna radiata and V. mungo. In future, studies may be conducted to examine the same on different crop growth and yield with the application of different chemical fertilizer and biofertilizer at different levels to enhance the crop production in this region.

\section{Acknowledgement}

The authors are thankful to the principal and academic members of Botany department, D. V. College, Orai (U. P.) for their guidance and departmental staff for their support and cooperation.

\section{REFERENCES}

[1] Abbasniayzare, S. K., Sedaghathoor, S., Padasht Dahkaei, M. N., "Effect of Biofertilizer Application on growth parameters of Spathiphyllum illusion", Am.-Eurasian J. Agric. \& Environ. Sci., 12, 5, 669-673, 2012.

[2] Akinrinde, E. A., Adigun, I. O., "Phosphorus-use efficiency by pepper (Capsicum frutescens) and okra (Abelmoschus esculentus) at different phosphorus fertilizer application levels on two tropical soils”, J. Appl. Sci., 5, 10, 1785-1791, 2005.

[3] Anjali, M. C., Dhananjaya, B. C., "Influence of different levels of phosphorus and PSB seed treatment on $\mathrm{P}$ fraction in soil at different growth stages of groundnut (Arachis hypogaea L.)”, Int. J. Curr. Microbiol. App. Sci., 6, 10, 216-224, 2017.

[4] Ashour, S. A., "Influence of bio-fertilizers and phosphorus application on growth and yield of potato", J. Agricultural Science, Mansoura Univ., 23, 7, 3351-3358, 1998.

[5] Awad, N. M., "The use of micro-organisms in ecological farming systems”, Ph.D. Thesis, Faculty of Science, Cairo University, pp 153, 1998.

[6] Baliah, N. T., "Phosphate Solubilizing Bacteria (PSB)- A novel PGPR for sustainable agriculture”, International Journal of Innovative Research in Science, Engineering and Technology, 7, 4, 3888-3895, 2018.

[7] Bashan, Y., Holguin, G., de-Bashan, L. E., “Azospirillum-plant relationships: physiological, molecular, agricultural and environmental advances”, Canadian J. Microbiol., 50, 521-577, 2004.

[8] Cakmakc, R. I., Aydyn, D. F., Sahin, A. F., "Growth promotion of plants by plant growth promoting rhizobacteria under greenhouse and two different field soil conditions”, Soil Biology and Biochemistry, 38, 1482-1487, 2006.

[9] Chandrasekar, B. R., Ambrose, G., Jayabalan, N., "Influence of biofertilizers and nitrogen source level on the growth and yield of Echinochloa frumentacea (Roxb.) Link”, Journal of Agricultural Technology, 1, 2, 223-234, 2005.

[10] Chang, S. T., Hayes, W. A., "Biology and cultivation of edible mushroom”, Academic Press Inc., New York, 1989.
[11] Dadkhah, A., "Effect of chemicals and biofertilizers on yield, growth parameters and essential oil contents of Funnel (Foeniculum vulgare Miller.)", Journal of Medicinal Plants and By-products, 2, 101-105, 2012.

[12] Dahal, Bhishma Raj, Bhandari, Subash, "Biofertilizer: A next generation fertilizer for sustainable Rice production”, Int. J. Grad. Res. Rev., 5, 1, 1-5, 2018.

[13] Duarah, M. D., Saikia, N., Deka Boruah, H. P., "Phosphate solubilizers enhance NPK fertilizer use efficiency in rice and legume cultivation”, 3 Biotech, 1, 4, 227-238, 2011.

[14] El-Khateeb, M. A., El-Madaawy, E., El-Attara, A., "Effect of some biofertilizers on growth and chemical composition of Chamaedorea elegans Mart. Seedlings”, Journal of Horticultural Science \& Ornamental Plant, 2, 3, 123-129, 2010.

[15] El-kkoly, M. A., Gomma, A. M., "Biofertilizers and their impact on forage yield and $\mathrm{N}$-content of millet under low level of mineral fertilizers", Annals of Agricultural Science, Moshtohor, 38, 2, 813-822, 2000.

[16] Ghetiya, K. P., Bhalu, V. B., Mathukia, R. K., Chovatia, P. K., Hadavani, J. K., "Effect of phosphate and potash solubilizing bacteria on nutrient uptake, quality parameter and economics of Popcorn (Zea mays L. Var. Everta)”, Int. J. Pure App. Biosci., 7, 1, 216-223, 2019.

[17] Kamal, Shashi, Mohit, Kumar, Raghav, Rajkumar, Manoj, "Effect of biofertilizers on growth and yield of tomato (Lycopersicon esculentum Mill)”, Int. J. Curr. Microbiol. App. Sci., 7, 2, 2542-2545, 2018.

[18] Khan, M. S., Zaidi, A., Wani, P. A., "Role of phosphate-solubilising micro organisms in sustainable agriculture- A review", Agronomy for sustainable Development, 27, 29-43, 2007.

[19] Kiran, Pal, Amit, Kudesia, Rajdeep, "Soil quality of degraded land of Bundelkhand region with special reference to Jhansi district of Uttar Pradesh”, Journal of Phytology, 1, 5, 328-332, 2009.

[20] Kouchebagh, Sahar Baser, Bahram, Mirshekari, Farhad, Farahvash, "Improvement of corn yield by seed Biofertilization and Urea Application, World Applied Sciences Journal, 16, 9, 1239-1242, 2012.

[21] Kumar, Dinesh, Arvadiya, L. K., Desai, K. L., Usadadiya, V. P., Patel, A. M., "Growth and yield of Chickpea (Cicer arietinum L.) as influenced by graded levels of fertilizers and biofertilizers”, The Bioscan, 10, 1, 335-338, 2015.

[22] Kumar, M. Santhosh, Reddy, G. Chandramohan, Phogat, Mamta, Korav, Santosh, "Role of bio-fertilizers towards sustainable agricultural development: A review”, Journal of Pharmacognosy and Phytochemistry, 7, 6, 1915-1921, 2018.

[23] Lin, W., Okon, Y., Hardy, R. W. F., "Enhanced mineral uptake by Zea mays and Sorghum bicolor”, Appl. Environ. Microbiol., 45, 1775-1779, 1983.

[24] Mahfouz, S. A., Sharaf-Eldin, M. A., "Effect of mineral vs. biofertilizer on growth, yield and essential oil content of fennel (Foeniculum vulgare Mill.)”, International Agrophysics, 21, 361-366, 2007.

[25] Mondal, S., Dutta, S., Banerjee, A., Banerjee, S., Datta, R., Roy, P., Podder, A., Roy, R., Basu, P., Dasgupta, P., Saha, 
D., "Production and application of phosphate solubilizing bacteria as biofertilizere: field trial at Maize field, Uchalan, Burdwan district, West Bengal”, International Journal of Environmental \& Agriculture Research, 3, 1, 1-9, 2017.

[26] Okon, Y., “The physiology of Azospirillum in relation to its utilization as inoculums for promoting growth of plants. In "Nitrogen fixation and $\mathrm{CO}_{2}$ metabolism", Eds. P. W. Ludden and O. E. Burris, Elsevier, New York, 165-174, 1985.

[27] Petering, H. G., Wolnen, W., Hibbard, R. D., "Determination of chlorophyll and carotene in plant tissue", Ind. Eng. Chem. Anal. Ed., 12, 148-151, 1940.

[28] Punith Kumar, L. M., Indira, M., “Trends in fertilizer consumption and foodgrain production in India: A Cointegration analysis”, SDMIMD Journal of Management, 8, 2, 45-50, 2017.

[29] Reddy, B. P., Swamy, S. N., "Effect of farmyard manure, phosphate solubilizing bacteria and phosphorus on yield and economics of black gram (Phaseolus mungo)", Indian Soc. Soil Sci., 47, 4, 805-808, 2000.

[30] Rashid, A., Mir, M. R., Hakeem, K. R., "Biofertilizer use for sustainable agricultural production”, Plant, Soil and Microbes, Springer, Cham., 163-180, 2016.

[31] Rathor, G., Sharma, S. K., Chopra, N., Singh, K., Chourey, G., "Management of phosphorus fertilizer in maize crop using PSB (Phosphorus solubilising bacteria) in Vertisol”,
Int. J. Pure App. Biosci., 6, 2, 253-258, 2018.

[32] Selosse, M. A., Baudoin, E., Vandenkoornhyse, P., "Symbiotic microorganisms, a key for ecological success and protection of plants”, Comptes Rendus Biologies, 327, 639-648, 2004.

[33] Singh, R.P., Gupta, S.C., Yadav, A.S., "Effect of levels, and sources of phosphorus and PSB on growth and yield of black gram (Vigna mungo L. Hepper)”, Legume Res., 31, 2, 139-141, 2008.

[34] Tomar, R. A. S., Nemdeo, K. N., Raghu, J. S., "Efficacy of PSB and biofertilizer with phosphorus on growth and yield of gram (Cicer arietinum)”, Indian Journal of Agronomy, 40, 412-415, 1996.

[35] Turkoglu, Nalan, Alp, Sevket, Cig, Arzu, "Effect of Diamonium Phosphate (DAP) fertilization in differnet doses on bulb and flower of Narcissus", American-Eurasian J. Agric. \& Environ. Sci., 4, 5, 595-598, 2008.

[36] Vessey, J. K., "Plant growth promoting rhizobacteria as bio-fertilizers”, Journal of Plant and Soil, 225, 43, 571-86, 2003.

[37] Vikram, A., Algawadi, A. R., Hamzehzarghani, H., Krishnaral, P. U., "Efficacy of Phosphate Solubilizing Bacteria on the yield and phosphorus uptake of green gram (Vigna radiata (L.) Wilczek)", The Americas Journal of Plant Science and Biotechnology, 80-84, 2008. 